\title{
O GOVERNO TAMBÉM TE DEVE? ESCOLHA A FILA E ENTRE NELA!
}

Coluna publicada em 14.11.2017: <https://www.conjur.com.br/2017-nov-14/ contas-vista-governo-tambem-te-escolha-fila-entre-nela $>$

A já longa recessão está produzindo no setor público um fenômeno semelhante ao que ocorre no setor privado. Quando as empresas ou mesmo pessoas físicas passam por dificuldades financeiras, e se aproximam da falência, a fila dos credores que bate à porta para receber o que lhes é devido cresce sem parar.

$\mathrm{Na}$ administração pública, as peculiaridades do regime jurídico de direito público produzem algumas situações no mínimo curiosas. Temos um verdadeiro "regime jurídico das filas de credores", gerando um caótico “ordenamento jurídico das filas".

A mais famosa delas é, sem dúvida, a fila dos precatórios. Fila com previsão e regras constitucionais! Não é desarrazoado reconhecer que conseguimos transformar uma fila em direito fundamental, verdadeira cláusula pétrea constitucional.

Já tratei do tema há algum tempo, na coluna No samba dos precatórios quem dança são os credores, nesta edição, p. 417-422, mas a véspera do Dia da Proclamação da República é uma boa oportunidade de voltar a tratar de uma atitude nada republicana que acompanha nosso país antes mesmo de se tornar uma República. A origem dos precatórios no Brasil, que remonta a registros na Torre do Tombo em Portugal, antes da descoberta do País, deve-se a uma questão secundária de ordem processual, qual seja, à impenhorabilidade dos bens públicos, e pode ser notada com clareza no art. 532 do Decreto 3.084/1898: "Não são sujeitos à penhora os bens da União, dos Estados ou das Camaras Municipaes, bem como as suas rendas, os quaes só devem ser despendidos de accordo com os respectivos orçamentos" (art. 532), e mais à frente, "Sendo a Fazenda condemnada por sentença a algum pagamento, estão livres de penhora os bens nacionaes, os quaes não podem ser 
alienados sinão por acto legislativo. A sentença será executada, depois de haver passado em julgado e de ter sido intimado o procurador da Fazenda, si este não lhe offerecer embargos, expedindo o juiz precatoria ao Thesouro para effectuar-se o pagamento" (Art. 41). ${ }^{1}$

Uma forma de organizar o pagamento decorrente de sentenças judiciais contra a Fazenda Pública, que nunca funcionou a contento ante o péssimo e arraigado hábito do Poder Público de não honrar suas dívidas. Hábito que, como se pode notar, vem de épocas bem remotas, e o passar dos anos não o alterou - ao que parece, até agravou. Criou-se uma "bola de neve" de débitos do setor público que resultou em um verdadeiro "monstro" difícil de controlar.

O inadimplemento do Poder Público já era uma grande preocupação por parte dos Constituintes republicanos, que fizeram os precatórios entrarem no texto da Constituição de 1934, constitucionalizando-os. Surge, no anteprojeto, artigo 74, a "fila dos precatórios". O mais interessante são as palavras dos constituintes, que podem ser reproduzidas, sem alteração, por qualquer parlamentar hoje em dia: “i) A desordem financeira em muitos Estados não se manifesta apenas na cessação de pagamento da sua dívida fundada, mas também e principalmente pela desordem no pagamento da dívida flutuante, sujeito ao regime do favoritismo, quando não das negociatas dos intermediários e pela desordem no pagamento dos funcionários: Contas de amigos se processam e pagam rapidamente, enquanto as de adversários ou dos que se não submetem a extorsões, ficam relegadas ao abandono, mesmo que sejam cartas de sentença. Relativamente a estas últimas na esfera federal, tem o anteprojeto excelente dispositivo no art. 74. Estende-o a emenda aos Estados, fazendo-o atingir também as contas comuns, sancionado tudo pela intervenção". ${ }^{2}$

Várias Constituições vieram, mas o problema permaneceu. As Constituiçóes mudam, mas a inadimplência continua. A inadimplência é o que parece, de fato, ser a verdadeira "cláusula pétrea".

Chegamos à atual Constituição, que detalhou os precatórios e suas regras em seu art. 100. E o art. 33 do Ato das Disposiçôes Constitucionais Transitórias deu início aos muitos parcelamentos que vieram na sequência. A inadimplência continuou firme e forte, e tivemos um dos maiores exemplos de que o Direito Financeiro não é levado a sério.

\footnotetext{
1 Sobre o tema, veja-se o detalhado texto de Eurípedes Faim Filho, Evolução histórica dos precatórios no Brasil até a Constituição de 1988. Escola Paulista da Magistratura (<www.epm.tjsp. jus.br>, disponível desde $1^{\circ}$ de agosto de 2016, acesso em 10 nov. 2016).

2 Eurípedes Faim, artigo citado anteriormente.
} 
A vã tentativa de regularizar a situação vem por meio de sucessivas emendas constitucionais, instituindo parcelamentos sobre parcelamentos, com preferências e "superpreferências", e cria-se uma fila com "subfilas", em um sistema que prima pelo caos. Mas não há nada tão ruim que não possa piorar. A famigerada "Lei de Murphy" não perde a oportunidade de mostrar sua força quando se trata de Direito Financeiro.

Como boa parte das normas jurídicas atualmente publicadas, a Emenda Constitucional 62, de 2009, que instituiu o "regime especial de pagamento de precatórios”, foi seguida de impugnação por meio de várias ações diretas de inconstitucionalidade (ADIs 4357, 4372, 4400 e 4425). Uma verdadeira nova fase já institucionalizada do processo legislativo brasileiro, que não mais termina com a sanção e publicação da norma, mas sim com o julgamento das inevitáveis ADIs que seguem à sua publicação.

Depara-se então com a suspensão liminar dos efeitos de parte da referida emenda, cujo julgamento foi "fatiado", ante o reconhecimento pelo STF da violação de um verdadeiro "cardápio" de cláusulas pétreas (art. 5, caput e XXII, XXXV, XXXVI, entre outros). ${ }^{3}$ Seguem-se decisões para modular seus efeitos, ${ }^{4}$ embargos de declaração, até que exsurge outra tentativa de "pôr ordem na casa" com mais uma emenda constitucional (EC 94, de 4 de outubro de 2017).

A essa altura já devem estar formando filas de intérpretes tentando compreender o funcionamento das inúmeras filas! E nada do dinheiro dos credores...

Há quem diga que brasileiro gosta de filas. É só ver uma que já entra. Se tem fila, deve ter alguma coisa boa no final dela, pensam. Gostar de filas e transformá-las em direito fundamental petrificado na Constituição parece um exagero. Mas é o que temos.

E se esta fila constitucional pode deixar muitos com um ar de incredulidade e indignação, pior são as outras, que nem organizadas estão. Um salve-se quem puder.

A anualidade, histórico princípio orçamentário, expressamente consagrado na legislação, ${ }^{5}$ já há muito precisa de uma reinterpretação, pois não mais condiz com a atual organização do sistema de planejamento orçamentário, em que a plurianualidade é uma característica inerente à moderna gestão pública. Vê-se deixar algu-

ADI 4357, rel. Min. Ayres Britto, redator do acórdão Min. Luiz Fux, Plenário, j. 14.3.2013.

ADI 4375, Questão de Ordem, rel. Min. Luiz Fux, Plenário, j. 25.3.2015.

Lei 4.320/1964, art. 2: "A Lei do Orçamento conterá a discriminação da receita e despesa de forma a evidenciar a política econômica financeira e o programa de trabalho do Govêrno, obedecidos os princípios de unidade universalidade e anualidade”. 
mas distorções, como é o caso dos chamados restos a pagar, "despesas empenhadas mas não pagas até o dia 31 de dezembro" (Lei 4.320/1964, art. 36), cujo uso foi de tal forma deturpado que se transformou em um grave problema de responsabilidade fiscal, e teve de ser regulado pela LRF (Lei de Responsabilidade Fiscal), fazendo do art. 42 um dos que mais preocupa os gestores públicos. $\mathrm{O}$ abuso em se transferirem despesas de final de exercício para o ano seguinte foi tão grande que muitos entes da federação hoje têm verdadeiros "orçamentos paralelos" de compromissos a cumprir. E dessa vez, sem fila, sem Constituição, sem regulamentação... Um verdadeiro "caos" de credores que se amontoam junto ao Poder Público na tentativa de ver satisfeitos seus créditos. E que não se atrevem a judicializar a cobrança, pois sabem que isso só os levará a trocar uma fila caótica e incerta por outra organizada e com a certeza de que levarão por vezes décadas para receber. ${ }^{6}$

Recentemente descobriu-se que a caótica situação financeira de muitos entes federados levou governantes a criarem a "fila da caderneta", ou "fila do fio do bigode". Ao se depararem com intransponíveis dificuldades para contratar e receber recursos públicos, tendo em vista as sanções a que já estão sujeitos pelo descumprimento das normas de finanças públicas, sucumbiram à tentação de deixar a Constituição e as leis de lado. Ante a irresponsabilidade fiscal de muitos governos que se sucederam, passaram a usar a nova técnica de contratos "secretos", "de gaveta", garantidos pelo "fio do bigode", à semelhança dos antigos armazéns das pequenas cidades. Empreiteiros e prestadores de serviços públicos passaram a "vender fiado". $\mathrm{Na}$ era da moderna gestão pública, voltamos às cadernetinhas de anotações de dívidas. $^{7}$

Mais uma fila, e dessa vez sem Constituição, sem lei, sem ordem, sem nada.

Mas não terminou. Tem mais. Ou melhor, terá mais. Já temos as filas futuras, e um futuro que está muito próximo, se é que já não chegou, em alguns entes da federação.

Não satisfeito com o caos já instalado, o Poder Público não deixa a criatividade cessar, e a busca por recursos levou à descoberta da "mina de ouro" dos depósitos judiciais. A Lei Complementar 151, de agosto de 2015, permitiu o uso desses valores depositados pelas partes em processos judiciais para pagamento dos próprios precatórios e outros itens. Um risco, que não é difícil de prever, causará (ou já causou) um novo foco de inadimplência. E uma nova fila de credores.

O final de ano, as dividas e os "restos a pagar", nesta edição, p. 215-218.

7 Vivemos no país das finanças públicas mal-assombradas, nesta edição, p. 177-182. 
Nesta quarta-feira, dia 15, comemora-se a Proclamação da República. Uma excelente oportunidade para que se relembrem os valores republicanos. Pagar o que se deve está - ou deveria estar - entre eles. Essas filas não são exatamente o que se espera de um Estado que preza por esses valores.

E, para aqueles que estão aguardando pacientemente na fila, é bom aproveitar o tempo para refletir sobre esses valores republicanos. Principalmente aqueles que fazem o Estado funcionar ou com ele se relacionam. É preciso colocar o bem comum acima dos interesses pessoais. Os dias atuais evidenciam que esses valores se perderam e precisam ser rapidamente recuperados. E não estão somente nas filas dos precatórios, mas no uso dos recursos públicos em todos os seus aspectos. $\mathrm{O}$ Direito Financeiro é farto em exemplos: na concessão e uso adequado de renúncias de receitas, na aplicação correta de subvenções, na higidez das licitações, nos concursos públicos meritocráticos, sem proteções e apadrinhamentos.

A República começa em cada um de nós. Só teremos um país verdadeiramente republicano quando todo cidadão tiver dentro de si, e praticar, os valores republicanos. 
